\title{
The Role of Basic Business Skills Development and Their Influence on South African Small, Medium
} and Micro Enterprise Sustainability

\author{
Juan-Pierré Bruwer, Judith Smith \\ Cape Peninsula University of Technology, South Africa \\ BruwerJP@cput.ac.za
}

\begin{abstract}
South African Small, Medium and Micro Enterprises (SMMEs) have received vast amounts of attention from both government and scholars over the years, mainly due to the socio-economic value they add to the national economy. Notwithstanding the importance of these business entities to the South African economy, prior research suggests that South African SMMEs have one of the worst sustainability rates in the world; mainly attributable to the influence of unmanaged economic factors. Included in these economic factors is the matter of a scarcity of skills, particularly that of basic business skills. Though limited research has been conducted on the individual business skills which require development in South African SMMEs the perception was formulated that the development of basic business skills in these business entities may have a positive influence on their attainment of key businesses objectives in the foreseeable future. As such, empirical research was performed which fell within the positivistic research paradigm; data were gleaned from South African SMME management through means of a questionnaire. Stemming from the results, it was found that although there is a dire need for the development of basic business skills in South African SMMEs. It can be argued that some basic business skills were more important to develop than others as only a few had a positive influence on the attainment of business objectives.
\end{abstract}

Keywords: Basic business skills, Small, Medium \& Micro Enterprises, South Africa, sustainability

\section{Introduction}

In 1996 South African Small, Medium and Micro Enterprises (SMMEs) were first formally recognised by the South African government as drivers of the national economy (Bruwer, 2016). According to legislation ${ }^{1}$ these business entities have the responsibility to attain three main socio-economic objectives. They pertain to the decreasing of national unemployment through job-creation, the diminishing of national poverty through wealth-dissemination, and the boosting of the national economy through adding value to the national Gross Domestic Product (GDP) (South Africa, 1996).Despite the fact that South African SMMEs make up approximately $90 \%$ of all business entities operating in the country (Mouloungui, 2012), while simultaneously contributing up to 57\% to the national GDP (Naidoo \& Urban, 2010; Thabethe, 2013), national unemployment ${ }^{2}$ and national poverty ${ }^{3}$ have not improved over the past two decades since the formal recognition of SMMEs by national government (Biyase, 2009;Cant \&Wiid, 2013;Moloi, 2013).The foregoing is placed in perspective when taking into account that more than $50 \%$ of South Africans live in poverty; making ends meet on $\pm R 25.00$ per day / $\pm R 779.00$ per month (Cole, 2015;Grant, 2015). Additional evidence to support this view is provided through the statistics presented in Table 1. It is evident from Table 1that both unemployment and poverty are still major problems in South Africa. Particularly between 2000 and 2016 there was an increase of an estimated 3.3 million unemployed South Africans (an increase of 28.9\%)while the Gini-index hovered between 0.60 and 0.69 over the same timeframe. Hence, taking into account the three socio-economic objectives which South African SMMEs are responsible to achieve, it is fair to assume that the sustainability ${ }^{4}$ of these business entities is very weak.

1In the context of this paper, the term "legislation" refers to the National Small Business Act No. 102 of 1996 and the National Small Business Amendment Act No. 26 of 2003.

2South African unemployment is generally measured by the unemployment rate, as based on the narrow definition; referring to a percentage of a country's estimated population who are unemployed and actively searching for employment opportunities (Ashipala, 2010;Fransman, 2014).

3Poverty in South Africa is measured by the Gini-coefficient; a measurement which shows how equally wealth is disseminated in a country - 0 represents absolutely equal dissemination of wealth while 1 represents absolute unequal dissemination of wealth (Meyer, 2016).

${ }^{4}$ Sustainability pertains to the attainment of relevant business objectives through the fulfilment of economic responsibilities, social responsibilities and/or environmental responsibilities, all with the intent to remain in operation 
Table 1: Summary of poverty, unemployment and estimated population size of South Africa between 2000 and 2016

\begin{tabular}{|c|c|c|c|c|c|}
\hline Year & $\begin{array}{l}\text { Gini- } \\
\text { coefficient }\end{array}$ & $\begin{array}{l}\text { Unemployment } \\
\text { rate }\end{array}$ & $\begin{array}{l}\text { Estimated } \\
\text { population size }\end{array}$ & $\begin{array}{l}\text { Estimated } \\
\text { citizens }\end{array}$ & unemployed \\
\hline 2000 & 0.68 & $25.4 \%$ & 44.9 million & 11.4 million & \\
\hline 2001 & 0.65 & $27.9 \%$ & 45.1 million & 12.6 million & \\
\hline 2002 & 0.60 & $29.2 \%$ & 46.2 million & 13.5 million & \\
\hline 2003 & 0.60 & $29.6 \%$ & 47.0 million & 13.9 million & \\
\hline 2004 & 0.60 & $27.1 \%$ & 47.7 million & 12.9 million & \\
\hline 2005 & 0.69 & $26.6 \%$ & 48.4 million & 12.9 million & \\
\hline 2006 & 0.65 & $25.6 \%$ & 49.0 million & 12.5 million & \\
\hline 2007 & 0.64 & $23.2 \%$ & 50.0 million & 11.6 million & \\
\hline 2008 & 0.63 & $22.5 \%$ & 50.3 million & 11.3 million & \\
\hline 2009 & 0.63 & $23.7 \%$ & 51.0 million & 12.1 million & \\
\hline 2010 & 0.69 & $24.9 \%$ & 51.6 million & 12.8 million & \\
\hline 2011 & 0.63 & $24.8 \%$ & 52.2 million & 12.9 million & \\
\hline 2012 & 0.63 & $24.9 \%$ & 52.8 million & 13.1 million & \\
\hline 2013 & 0.63 & $24.7 \%$ & 53.4 million & 13.2 million & \\
\hline 2014 & 0.65 & $25.1 \%$ & 54.0 million & 13.6 million & \\
\hline 2015 & 0.68 & $25.4 \%$ & 54.5 million & 13.8 million & \\
\hline 2016 & $\mathrm{~N} / \mathrm{A}$ & $26.7 \%$ & 55.0 million & 14.7 million & \\
\hline
\end{tabular}

Sources: (Tregenna \& Tsela, 2012; OECD, 2015; Trading Economics, 2017; Worldometers, 2017; World Bank, 2017).

The assumption above is supported by previous research (Wiese, 2014) where it was found that the sustainability of South African SMMEs is believed to be among the worst in the world. This is mainly the case since approximately $75 \%$ of these business entities fail after being in existence for only three years (Fatoki, 2014; Siwangaza, Smit, Bruwer, \& Ukpere, 2014). Despite the fact that previous research (Kunene, 2008; SAICA, 2015) has identified an array of factors which adversely influence the overall sustainability of South African SMMEs, the two most notable factors include macro-economic factors and micro-economic factors (Radas \& Božić, 2009). These two factors are briefly elaborated on below (Bruwer \& Van Den Berg, 2017):

- Macro-economic factors: Those factors which stem from outside a business entity, which impacts on the economy of a country, including its inhabitants (both legal- and natural persons) over which management have limited control. Examples of such factors include inter alia changes in interest rates, changes in inflation rates, changes in taxation rates, national service delivery, supply and demand and changes to legislation.

- Micro-economic factors: Those factors which stem from inside a business entity, which impacts on the stakeholders of the relevant business entity (both legal- and natural persons) over which management have reasonable control. Examples of such factors include inter alia, changes in customer satisfaction, productand/or service quality, basic business skills of relevant stakeholders and changes in financial performances and/or financial positions.

According to previous studies(Brand, Du Preez, \& Schutte, 2007; Olawale \& Garwe, 2010; Herrington, Kew, \& Kew, 2010; Cant, Erdis, \& Sephapo, 2014) a major micro-economic factor which adversely influences the sustainability of South African SMMEs is a lack of basic business skills 5 .The phenomena of scarce skills stems directly from the political history of South Africa (Apartheid) where the majority of the population was excluded from reasonable access to fair opportunities such as education, freedom of movement, and freedom

for the foreseeable future (Van Calker, Berentsen, Giesen, \& Huirne, 2005; Jeon, Amekudzi, \& Guensler, 2010;Lebacq, Baret, \& Stilmant, 2013).

In a recent study, (Mamabolo, Kerrin, \& Kele, 2017) describe basic business skills as those skills pertaining to business management, financial management, human resource management and marketing. Albeit the latter, the term "basic business skills" is not clearly conceptualized in a South African SMME dispensation. 
of association. In addition, over the past two decades of democracy (post-Apartheid), in an attempt to "bridge the gap" in relation to scarce skills, education policies were updated which favour throughput over meritorious achievements which, in turn, adversely impacted literacy-levels across the board (South Africa, 2016). This has resulted in poorly equipped people entering the business world, including entrepreneurs and employees of SMMEs. Hence, using the above as a basis, the inference can be made that if basic business skills are developed in South African SMMEs, it may have a positive influence on the attainment of their business objectives in the foreseeable future. As such, for this research study, the following two hypotheses were developed and tested:

H1: Basic business skills of members of management, if developed in South African SMMEs, have a statistically significant positive influence on the attainment of their key objectives.

$\mathrm{H}_{2}$ : Basic business skills of employees, if developed in South African SMMEs, have a statistically significant positive influence on the attainment of their key objectives.

For the remainder of this study, discussion takes place under the following headings: 1) literature review and conceptualisation of business skills, 2) research design, methodology and methods, 3) results and discussion, and 4) conclusion.

\section{Literature Review and Conceptualisation of Business Skills}

The lack of scarce skills is a major socio-economic problem for South Africa (Ramukumba, 2014;Mateus, Allen-Ile, \& Iwu, 2014;World Economic Forum, 2014). This is specifically the case since the lack of scarce skills has been found to have an adverse influence on the national economy in the sense that it excludes a large proportion of South African citizens from participating in economic activities (Polity, 2013). The lack of scarce skills is believed to stem directly from inter alia poor quality education, the lack of competent teachers, the lack of proper training opportunities, and the emigration of subject matter experts (IOL, 2008; Höppli, 2014; Duncan, 2014). While being aware of the issue, the South African government, in recent times, has highlighted an array of scarce skills which should be developed ${ }^{6}$ by accredited education providers through identifying occupations that are in high demand and/or vacancies which are not easily fillable (DHET, 2015). Before elaborating further, it is important to conceptualise the term "skills" within the ambit of this study. The term "skills" is generally regarded as abilities, attributes and/or areas of expertise (Dictionary, 2017), this term is viewed differently by scholars around the globe. For example, (Kirschner, Van Vilsteren, Hummel, \& Wigman, 1997) describes "skills" as actions which can be measured according to how well it is being carried out, while (García-Magariño, Gómez-Sanz, \& Fuentes-Fernández, 2009) views "skills" as the capability to fulfil a goal. In addition, (Demetriou, Shayer, \& Efklides, 2016) explain that "skills" serve as a control structure governing a specific class of actions that a person can perform in a specific context and (Thórisson et al., 2014) aver "skills" to be phenomena which consist of learning models and their context and sequence of execution. Taking into account the above, and for this research study, the term "skills" was conceptualised as follows:

Those abilities which can be learned and mastered, which can also be utilised and/or relied on when performing certain tasks, with the main intent to achieve certain pre-determined objectives.

Reverting to the scarce skills which need development in a South African dispensation, there exists a plethora of skills which are regarded as scarce to the national economy (DHET, 2015). Some of these scarce skills also relate to basic business skills (Cameron, 2014;FASSET, 2015). Taking into account the conceptualisation of the term "skills" above, it becomes apparent that basic business skills will pertain to attributes, knowledge and/or competencies which can be used and/or relied on in a business dispensation. This view is supported by (Mittelstaedt \& Wiepcke, 2007) who regard the concept of "business skills" as abilities and/or capacities

6Though that the manner in which skills can be developed falls beyond the scope of this study, it is worth noting that the latter strongly relates to cognitive development, as supported by an array of theories (Fischer, 1980), (Masson, 1990), (Anderson \& Krathwohl, 2001). 
which can be used to enhance the economy, efficiency and effectiveness of a business. Thus, using the above as a foundation, the term "basic business skills" was conceptualised in this study as follows:

Those fundamental abilities which can be learned and mastered, that are utilised and predominantly relied on when performing business-related tasks, with the main intent to achieve certain pre-determined business objectives.

In fundamental nature basic business skills should assist relevant stakeholders (i.e. owners, managers and employees) to perform business-related tasks in order to execute relevant business operations, with the main intent to attain pre-determined business objectives, all with the intent to assist a business to remain in operation for the foreseeable future (Panco \& Korn, 1999; Dahlqvist, Davidsson, \& Wiklund, 2000; Thornhill \& Amit, 2003).A non-exhaustive list of the most scarce basic business skills is shown and described in Table 2(Woolard, Kneebone, \& Lee, 2003; Daniels, 2007).

Table 2: Non-exhaustive list of scarce business-related skills

\begin{tabular}{|c|c|}
\hline Skill & Description \\
\hline Accounting skills & $\begin{array}{l}\text { Those competencies pertaining to the discipline of accounting, as } \\
\text { required by a person to competently perform functions in relation to } \\
\text { the: 1) recording of transactions in the books of a business, 2) reporting } \\
\text { on the financial situation of a business, and 3) providing } \\
\text { recommendations on how the financial situation of a business can be } \\
\text { improved on. }\end{array}$ \\
\hline Administrative skills & $\begin{array}{l}\text { Those skills related to running a business or keeping an office organised } \\
\text { through means of: 1) virtual organisation, 2) file management, 3) } \\
\text { performing planning activities, 4) solving office-related problems, 5) } \\
\text { communication with stakeholders (verbal and non-verbal), and 6) time } \\
\text { management activities. }\end{array}$ \\
\hline Business management skills & $\begin{array}{l}\text { Those competencies related to holistic controlling-, leading-, organising- } \\
\text { and planning activities in a business. }\end{array}$ \\
\hline Communication skills & $\begin{array}{l}\text { Those skills that build trust and strong relationships between applicable } \\
\text { stakeholders of a business entity through means of inter alia 1) active } \\
\text { listening abilities, 2) proper non-verbal methods, and 3) proper verbal } \\
\text { methods }\end{array}$ \\
\hline Computer literacy skills & $\begin{array}{l}\text { Those skills required to appropriately use computers and related } \\
\text { technology efficiently Such skills may include, among other, data } \\
\text { capturing, word processing, and electronic communications. }\end{array}$ \\
\hline Conflict management skills & $\begin{array}{l}\text { Those skills that limit the negative aspects of conflict while } \\
\text { simultaneously harnessing the positive aspects of conflict so as to } \\
\text { enhance effectiveness and/or performance in a business entity. }\end{array}$ \\
\hline Decision making skills & $\begin{array}{l}\text { Those skills involved in choosing between two or more courses of action } \\
\text { towards possible solutions to a given problem. }\end{array}$ \\
\hline Entrepreneurial skills & $\begin{array}{l}\text { Those skills which are used to create, organise and manage a business } \\
\text { entity successfully. }\end{array}$ \\
\hline Financial management skills & $\begin{array}{l}\text { Those skills required to efficiently and effectively manage money in } \\
\text { such a manner to accomplish the financial objectives of a business } \\
\text { entity. }\end{array}$ \\
\hline Leadership skills & $\begin{array}{l}\text { Those skills required to make thoughtful decisions about an } \\
\text { organisation's mission and objectives, and properly allocate resources } \\
\text { to achieve them. }\end{array}$ \\
\hline Legal skills & $\begin{array}{l}\text { Those skills required to understand the legal aspects and legislative } \\
\text { requirements to which a business entity needs to take note of and/or } \\
\text { comply with. }\end{array}$ \\
\hline Listening skills & $\begin{array}{l}\text { Those skills that enable one to pay attention to and effectively interpret } \\
\text { what other people are saying. }\end{array}$ \\
\hline Literacy skills & Those attributes that are required to read and write. They include such \\
\hline
\end{tabular}




\begin{tabular}{|c|c|}
\hline Skill & Description \\
\hline & $\begin{array}{l}\text { things as awareness of the sounds of language, awareness of print, and } \\
\text { the relationship between letters and sounds. }\end{array}$ \\
\hline Management skills & $\begin{array}{l}\text { Those skills which pertain to that of problem-solving, decision-making, } \\
\text { planning, delegation, communication, and time management. }\end{array}$ \\
\hline Marketing skills & $\begin{array}{l}\text { Those skills that enable a set of processes for creating, communicating } \\
\text { and delivering value to customers and for managing customer } \\
\text { relationships in ways that benefit a business entity and its applicable } \\
\text { stakeholders. }\end{array}$ \\
\hline Mathematical skills & $\begin{array}{l}\text { The ability to understand and analyse numerical information and to } \\
\text { make the correct conclusions and decisions. }\end{array}$ \\
\hline Motivational skills & $\begin{array}{l}\text { Those skills required to promote productivity in the employees of a } \\
\text { business entity. These include actions or strategies that will elicit a } \\
\text { desired behaviour or response by a stakeholder. }\end{array}$ \\
\hline Multitasking skills & $\begin{array}{l}\text { Those skills that enable an individual to perform more than one task at } \\
\text { any given time. }\end{array}$ \\
\hline Negotiation skills & $\begin{array}{l}\text { Those skills involving formal discussions between people who have } \\
\text { different aims or expectations, with the view to reaching an agreement } \\
\text { on mutual grounds. }\end{array}$ \\
\hline Organising skills & $\begin{array}{l}\text { Those skills required to use time, energy and resources effectively to } \\
\text { achieve goals set by a business entity. }\end{array}$ \\
\hline People skills & $\begin{array}{l}\text { Those skills required to communicate effectively with people in a } \\
\text { friendly way in the business environment both internally and externally. } \\
\text { This generally takes place by making use of sincere empathy. }\end{array}$ \\
\hline Planning skills & $\begin{array}{l}\text { Those skills that enable one to look ahead and accomplish goals or avoid } \\
\text { emotional-, financial-, physical- or social problems and ultimately allow } \\
\text { one to make and implement decisions. }\end{array}$ \\
\hline Presentation skills & $\begin{array}{l}\text { Those skills that are required to deliver effective and engaging } \\
\text { presentations to a variety of audiences. This includes the structuring a } \\
\text { presentation, its design, the tone of voice used and the body language of } \\
\text { the presenter. }\end{array}$ \\
\hline Problem-solving skills & $\begin{array}{l}\text { Those skills that follow a process of finding solutions to difficult or } \\
\text { complex issues related to a business entity. }\end{array}$ \\
\hline Research skills & $\begin{array}{l}\text { Those skills required to identify a problem, determine the informational } \\
\text { resources needed, to respond to the problem to adequately reduce } \\
\text { and/or eliminate the applicable problem through means of proper } \\
\text { recommendations }\end{array}$ \\
\hline Staff management skills & $\begin{array}{l}\text { Those skills required to manage all employees in a business entity, } \\
\text { including the development of staff skills through training and other } \\
\text { forms of staff development as well as the identification, development } \\
\text { and implementation of training needs and programs available for staff. }\end{array}$ \\
\hline Thinking skills & $\begin{array}{l}\text { Those skills that enable the mental processes to solve problems, make } \\
\text { decisions, ask questions, construct plans and evaluate ideas, among } \\
\text { other cognitive abilities. }\end{array}$ \\
\hline Time management skills & $\begin{array}{l}\text { Those skills that involve the process of planning and exercising } \\
\text { conscious control over the amount of time spent on specific activities, all } \\
\text { with the intent to increase effectiveness, efficiency or productivity. }\end{array}$ \\
\hline Writing skills & $\begin{array}{l}\text { Those skills that enable non-verbal communication through text that } \\
\text { allows a business entity's management to organise knowledge and } \\
\text { beliefs into convincing arguments through to relevant stakeholders, and } \\
\text { to convey the meaning of it through well-constructed written } \\
\text { documents which can take many forms }\end{array}$ \\
\hline
\end{tabular}

Sources: (Thornhill \& Amit, 2003; Strydom \& Tustin, 2003; Mughan, Lloyd-Reason, \& Zimmerman, 2004;Clover \& Darroch, 2005;Onoh, 2011;DHET, 2015;Mamabolo, Kerrin, \& Kele, 2017) 


\section{Methodology}

This study was empirical in nature ${ }^{7}$ and constituted survey research. In addition, this study was quantitative in nature (falling within the positivistic research paradigm) which entailed the collection of primary data from 500 respondents through means of questionnaires. The deployed questionnaires comprised 22 questions; 14 multiple choice questions, 3 checkbox questions, 4 Likert-scale questions and 2 ratio questions - rendering the questionnaire to be quantitative in nature and allowing for the study to fall within the positivistic research paradigm. For the Likert-scale questions both a five point Likert-scale $(1=$ strongly disagree, $2=$ disagree, $3=$ neither agree nor disagree, $4=$ agree, and $5=$ strongly agree) and a six point Likertscale $(1=$ not applicable, $2=$ strongly disagree, $3=$ disagree, $4=$ neither agree nor disagree, $5=$ agree, and $6=$ strongly agree) were used.

The targeted population was South African SMME members of management; all respondents had to adhere to the following delineation criteria:

- Respondents had to have decision-making power in their respective SMMEs.

- Respondents had to be actively involved in their SMMEs.

- Respondents had to have at least 1 year's managerial experience.

- Respondents had to be South African citizens.

- Respondents' SMMEs had to employ between 1 and 50 full-time employees.

- Respondents' SMMEs had to be regarded as "micro enterprises", "small enterprises" or "very small enterprises".

- Respondents' SMMEs had to be regarded as sole traders, partnerships or close corporations.

- Respondents' SMMEs had to be regarded as non-franchised.

- Respondents' SMMEs had to operate in the Cape Metropole.

- Respondents' SMMEs had to exist for at least 1 year.

- Respondents' SMMEs had to be based in the Fast Moving Consumer Goods (FMCG8)industry.

Furthermore, applicable ethical considerations were adhered to in this study. Particularly, all respondents voluntarily participated in this study and could withdraw from it at any time without being discriminated against. All information provided by respondents were handled with the highest levels of confidentiality, the anonymity of respondents was guaranteed and all respondents were safeguarded from physical harm.

\section{Results and Discussion}

For the remainder of this section, discussion takes place under the following headings: 1) demographical information on sampled SMMEs, 2) sustainability of sampled SMMEs, 3) basic business skills of employees, 4) basic business skills of management, 5) Basic business skills requiring development and their influence over the attainment of key objectives and overall sustainability.

Demographical information on sampled SMMEs: Stemming from the results, the following demographical information was evident for sampled SMMEs:

- $77.4 \%$ were sole traders, $8.8 \%$ were partnerships and $13.8 \%$ were close corporations.

- $100 \%$ were non-franchised business entities.

- $39.6 \%$ existed for between 1 and 5 years, 29\% existed for between 6 and 10 years and $31.4 \%$ existed for longer than 10 years.

7This study was also exploratory in nature as no previous studies have been conducted on the identified hypotheses, especially in a South African dispensation.

${ }^{8}$ The Fast Moving Consumer Goods industry is characterised by business entities which sell non-necessity and necessity products on which marginal mark-ups are placed, which have a lifespan of less than three years and are consumed regularly by customers (Bose \& Pekny, 2000;Nagarajan \& Sheriff, 2013). 
- $80.2 \%$ were micro enterprises (employed between 1 and 5 employees), $12.2 \%$ were very small enterprises (employed between 6 and 10 employees) and 7.6\% were small enterprises (employed between 11 and 50 employees).

- $100 \%$ operated in the FMCG industry.

- $100 \%$ operated in the Cape Metropole.

Thus, the inference can be made that the average sampled SMME was a non-franchised micro enterprise sole trader which have been in existence for between 1 and 5 years, while employing between 1 and 5 employees at a given time, while operating in the FMCG industry within the Cape Metropole.

In addition to the above, the following demographical information pertained to respondents (members of management) of sampled SMMEs:

- $35.8 \%$ were owners, $32.4 \%$ were managers and $31.8 \%$ were owner-managers.

- $53.6 \%$ had between 1 and 5 years' managerial experience, $27 \%$ had between 6 and 10 years' managerial experience and $19.4 \%$ had more than 10 years' managerial experience.

- $100 \%$ were South African.

- $100 \%$ were actively involved in their respective SMMEs.

- $100 \%$ had decision making power.

- $30.2 \%$ did not have a secondary qualification, $41.6 \%$ had a secondary qualification and $28.2 \%$ had a tertiary qualification.

Using the above as a basis, it can be inferred that the average respondent was a South African owner of an average SMME (see above), while being actively involved in the respective SMME and having decision making power; possessing between 1 and 5 years' managerial experience with a secondary qualification as highest qualification.

Sustainability of sampled SMMEs: To better understand the sustainability of sampled SMMEs, respondents were asked to rate their agreement of statements pertaining to the sustainability of their respective SMMEs through means of a 5 -point Likert-scale $1=$ strongly disagree, 2 = disagree, $3=$ neither agree nor disagree, 4 = agree, $5=$ strongly agree). Each statement started with a base sentence which read: "This business ..." A summary of the results is shown in Table 3.

Table 3: Respondents' perceptions on their respective SMMEs' attainment of key objectives

\begin{tabular}{|c|c|c|c|c|c|c|}
\hline This business ... & $\begin{array}{l}\text { Strongly } \\
\text { disagree }\end{array}$ & Disagree & $\begin{array}{l}\text { Neither } \\
\text { agree nor } \\
\text { disagree }\end{array}$ & Agree & $\begin{array}{l}\text { Strongly } \\
\text { agree }\end{array}$ & Mean \\
\hline Has more income than expenses & $0.80 \%$ & $5.00 \%$ & $19.40 \%$ & $56.20 \%$ & $18.60 \%$ & 3.87 \\
\hline Has more assets than liabilities & $0.60 \%$ & $6.20 \%$ & $17.80 \%$ & $53.20 \%$ & $22.20 \%$ & 3.90 \\
\hline Has sufficient cash on hand & $0.40 \%$ & $6.20 \%$ & $15.20 \%$ & $57.40 \%$ & $20.80 \%$ & 3.92 \\
\hline $\begin{array}{l}\text { Has a good reputation with } \\
\text { customers }\end{array}$ & $0.60 \%$ & $0.20 \%$ & $3.80 \%$ & $35.00 \%$ & $60.40 \%$ & 4.54 \\
\hline $\begin{array}{l}\text { Has a good reputation with } \\
\text { competitors }\end{array}$ & - & $1.20 \%$ & $20.40 \%$ & $47.00 \%$ & $31.4 \%$ & 4.09 \\
\hline $\begin{array}{l}\text { Has a good reputation with } \\
\text { suppliers }\end{array}$ & - & $0.60 \%$ & $6.00 \%$ & $39.80 \%$ & $53.60 \%$ & 4.46 \\
\hline $\begin{array}{l}\text { Will remain operational in the } \\
\text { foreseeable future }\end{array}$ & $0.40 \%$ & $0.40 \%$ & $6.20 \%$ & $42.40 \%$ & $50.60 \%$ & 4.42 \\
\hline Can be regarded as sustainable & $0.20 \%$ & $0.20 \%$ & $4.60 \%$ & $52.00 \%$ & $43.00 \%$ & 4.37 \\
\hline
\end{tabular}

Source: Researchers' own construct

Stemming from the results in Table 3, it appears that respondents regarded their respective SMMEs to be relatively sustainable; supported by mean scores for all line items in the range of 3.87 and 4.54 . In core respondents perceived their SMMEs to achieve relevant economic responsibilities (i.e. being profitable, liquid and solvent) while simultaneously having a sound reputation with applicable stakeholders. In essence, 
respondents also had the perception that that their SMMEs will remain operational for the foreseeable future. Although the results in Table 3 appear favourable, it should be noted that respondents may have been biased in their responses (respondent bias). In order to ensure that respondents' perceptions were reasonable, they were asked to provide insight on whether their respective SMMEs were achieving their applicable objectives. From the results, $2.20 \%$ indicated "no", $34.00 \%$ said "unsure" and $63.80 \%$ stated "yes". Taking into account that $95.00 \%$ of respondents viewed their respective SMMEs as sustainable while only $63.80 \%$ of respondents indicated that their SMMEs are achieving their applicable objectives, it is possible that respondents may have been biased in their responses. In order to test this view, internal consistency (reliability) was tested through means of calculating a Cronbach's Alpha value for the applicable Likert-scale question. A value of 0.625 was calculated which is below the acceptable 0.700 value. As such, it appears that respondents may have been biased with their answers provided.

Basic business skills of employees: In order to understand whether employees possessed basic business skills, respondents were asked to rate their agreement of relevant statements through means of a 6-point Likert-scale $(0=$ not relevant, $1=$ strongly disagree, $2=$ disagree, $3=$ neither agree nor disagree, $4=$ agree, $5=$ strongly agree). Each statement started with a base sentence which read: "In this business, employees need to have appropriately developed ..." A summary of the results is shown in Table 4.

Table 4: Respondents' perceptions on basic business skills required by employees

\begin{tabular}{|c|c|c|c|c|c|c|c|}
\hline $\begin{array}{l}\text { In this business, } \\
\text { employees need to have } \\
\text { appropriately developed }\end{array}$ & $\begin{array}{l}\text { Not } \\
\text { relevant }\end{array}$ & $\begin{array}{l}\text { Strongly } \\
\text { disagree }\end{array}$ & Disagree & $\begin{array}{l}\text { Neither } \\
\text { agree nor } \\
\text { disagree }\end{array}$ & Agree & $\begin{array}{l}\text { Strongly } \\
\text { agree }\end{array}$ & Mean \\
\hline Accounting skills & $46.80 \%$ & $5.80 \%$ & $12.80 \%$ & $15.40 \%$ & $16.00 \%$ & $3.20 \%$ & 1.58 \\
\hline Administrative skills & $40.00 \%$ & $2.80 \%$ & $17.40 \%$ & $9.40 \%$ & $24.60 \%$ & $5.80 \%$ & 1.93 \\
\hline $\begin{array}{l}\text { Business management } \\
\text { skills }\end{array}$ & $35.20 \%$ & $4.80 \%$ & $13.60 \%$ & $19.00 \%$ & $20.00 \%$ & $7.40 \%$ & 2.06 \\
\hline Communication skills & $2.00 \%$ & $1.80 \%$ & $6.20 \%$ & $11.60 \%$ & $54.40 \%$ & $24.00 \%$ & 3.87 \\
\hline Computer literacy skills & $38.20 \%$ & $6.00 \%$ & $10.40 \%$ & $15.20 \%$ & $18.80 \%$ & $11.40 \%$ & 2.05 \\
\hline Conflict management skills & $16.80 \%$ & $4.60 \%$ & $12.20 \%$ & $20.00 \%$ & $37.60 \%$ & $8.80 \%$ & 2.83 \\
\hline Decision making skills & $38.20 \%$ & $6.00 \%$ & $10.40 \%$ & $15.20 \%$ & $18.80 \%$ & $11.40 \%$ & 2.89 \\
\hline Entrepreneurial skills & $16.80 \%$ & $4.60 \%$ & $12.20 \%$ & $20.00 \%$ & $37.60 \%$ & $8.80 \%$ & 2.01 \\
\hline $\begin{array}{l}\text { Financial management } \\
\text { skills }\end{array}$ & $16.20 \%$ & $4.80 \%$ & $11.20 \%$ & $19.80 \%$ & $37.80 \%$ & $10.20 \%$ & 2.04 \\
\hline Leadership skills & $35.40 \%$ & $4.80 \%$ & $17.40 \%$ & $16.40 \%$ & $18.20 \%$ & $7.80 \%$ & 2.58 \\
\hline Legal skills & $36.60 \%$ & $4.60 \%$ & $11.60 \%$ & $17.20 \%$ & $25.00 \%$ & $5.00 \%$ & 0.95 \\
\hline Listening skills & $21.60 \%$ & $4.00 \%$ & $15.20 \%$ & $20.80 \%$ & $30.60 \%$ & $7.80 \%$ & 3.98 \\
\hline Literacy skills & $64.40 \%$ & $8.40 \%$ & $8.20 \%$ & $8.00 \%$ & $9.00 \%$ & $2.00 \%$ & 3.80 \\
\hline Management skills & $0.80 \%$ & $2.20 \%$ & $7.00 \%$ & $9.20 \%$ & $50.00 \%$ & $30.80 \%$ & 2.50 \\
\hline Marketing skills & $2.80 \%$ & $1.80 \%$ & $5.00 \%$ & $14.60 \%$ & $54.60 \%$ & $21.20 \%$ & 2.37 \\
\hline Mathematical skills & $24.40 \%$ & $3.80 \%$ & $13.00 \%$ & $24.00 \%$ & $25.80 \%$ & $9.00 \%$ & 3.25 \\
\hline Motivational skills & $26.60 \%$ & $4.60 \%$ & $16.20 \%$ & $18.20 \%$ & $26.40 \%$ & $8.00 \%$ & 2.97 \\
\hline Multitasking skills & $11.80 \%$ & $2.60 \%$ & $7.00 \%$ & $17.40 \%$ & $49.60 \%$ & $11.60 \%$ & 3.82 \\
\hline Negotiation skills & $14.80 \%$ & $4.00 \%$ & $12.20 \%$ & $19.40 \%$ & $37.60 \%$ & $12.00 \%$ & 3.00 \\
\hline Organising skills & $2.80 \%$ & $2.20 \%$ & $6.60 \%$ & $16.00 \%$ & $43.60 \%$ & $28.80 \%$ & 3.32 \\
\hline People skills & $15.60 \%$ & $3.40 \%$ & $8.40 \%$ & $21.20 \%$ & $40.80 \%$ & $10.60 \%$ & 4.00 \\
\hline Staff management skills & $9.40 \%$ & $2.60 \%$ & $9.00 \%$ & $17.40 \%$ & $49.20 \%$ & $12.40 \%$ & 2.21 \\
\hline Planning skills & $2.20 \%$ & $1.20 \%$ & $4.00 \%$ & $10.00 \%$ & $52.00 \%$ & $30.60 \%$ & 2.64 \\
\hline Presentation skills & $32.80 \%$ & $4.00 \%$ & $8.00 \%$ & $24.40 \%$ & $26.20 \%$ & $4.60 \%$ & 2.52 \\
\hline Problem-solving skills & $20.40 \%$ & $4.80 \%$ & $12.00 \%$ & $22.40 \%$ & $34.00 \%$ & $6.40 \%$ & 3.36 \\
\hline Research skills & $24.40 \%$ & $5.60 \%$ & $9.60 \%$ & $21.00 \%$ & $32.40 \%$ & $7.00 \%$ & 1.64 \\
\hline Thinking skills & $7.20 \%$ & $2.20 \%$ & $10.00 \%$ & $21.00 \%$ & $46.80 \%$ & $12.80 \%$ & 3.77 \\
\hline Time management skills & $43.40 \%$ & $9.20 \%$ & $12.20 \%$ & $14.60 \%$ & $16.80 \%$ & $3.80 \%$ & 3.63 \\
\hline Writing skills & $3.20 \%$ & $1.20 \%$ & $4.60 \%$ & $17.60 \%$ & $53.60 \%$ & $19.80 \%$ & 3.92 \\
\hline
\end{tabular}

Source: Researchers' own construct 
From the results in Table 49, it appears that it was not mandatory for employees to possess legal skills, research skills and accounting skills. Of all remaining basic business skills, the skills which were mostly required by employees, according to respondents, were as follows:

- Writing skills (82.60\% agreement).

- People skills (82.60\% agreement).

- Listening skills $(80.80 \%$ agreement).

- Administrative skills (78.40\% agreement).

- Literacy skills (75.80\% agreement).

- Thinking skills (73.40\% agreement).

- Multitasking skills (72.40\% agreement).

- Time management skills (68.20\% agreement).

Using the above as a basis, respondents were asked to describe the overall development of the basic business skills of their employees. From the results, $7.80 \%$ of respondents indicated that it was not well developed, $41.00 \%$ stated that it was developed on an average level, while $51.20 \%$ mentioned that it was well developed.

Basic business skills of management: Similarly, to the above, to ascertain whether management possessed basic business skills, respondents were also asked to rate their agreement of relevant statements through means of a 6-point Likert-scale $(0=$ not relevant, $1=$ strongly disagree, $2=$ disagree, $3=$ neither agree nor disagree, $4=$ agree, 5 = strongly agree). Each statement started with a base sentence which read: "In this business, management needs to have appropriately developed ..." A summary of the results is shown in Table 5 .

Table 5: Respondents' perceptions on basic business skills required by management

\begin{tabular}{|c|c|c|c|c|c|c|c|}
\hline $\begin{array}{l}\text { In this business, } \\
\text { management needs to } \\
\text { have appropriately } \\
\text { developed }\end{array}$ & $\begin{array}{l}\text { Not } \\
\text { relevant }\end{array}$ & $\begin{array}{l}\text { Strongly } \\
\text { disagree }\end{array}$ & Disagree & $\begin{array}{l}\text { Neither } \\
\text { agree } \\
\text { nor } \\
\text { disagree }\end{array}$ & Agree & $\begin{array}{l}\text { Strongly } \\
\text { agree }\end{array}$ & Mean \\
\hline Accounting skills & $18.60 \%$ & $2.00 \%$ & $9.40 \%$ & $12.80 \%$ & $39.80 \%$ & $17.40 \%$ & 3.05 \\
\hline Administrative skills & $13.20 \%$ & $1.40 \%$ & $6.60 \%$ & $10.00 \%$ & $45.20 \%$ & $23.60 \%$ & 3.43 \\
\hline $\begin{array}{l}\text { Business management } \\
\text { skills }\end{array}$ & $4.40 \%$ & $1.20 \%$ & $5.20 \%$ & $14.20 \%$ & $46.00 \%$ & $29.00 \%$ & 3.83 \\
\hline Communication skills & $0.40 \%$ & $0.60 \%$ & $1.20 \%$ & $8.00 \%$ & $38.60 \%$ & $51.20 \%$ & 4.37 \\
\hline Computer literacy skills & $20.00 \%$ & $5.00 \%$ & $8.20 \%$ & $13.20 \%$ & $28.80 \%$ & $24.80 \%$ & 3.00 \\
\hline $\begin{array}{l}\text { Conflict management } \\
\text { skills }\end{array}$ & $3.60 \%$ & $1.60 \%$ & $4.80 \%$ & $17.00 \%$ & $45.20 \%$ & $27.80 \%$ & 3.82 \\
\hline Decision making skills & $0.60 \%$ & $1.20 \%$ & $1.00 \%$ & $6.80 \%$ & $44.80 \%$ & $45.60 \%$ & 4.31 \\
\hline Entrepreneurial skills & $3.00 \%$ & $1.80 \%$ & $7.80 \%$ & $18.20 \%$ & $33.20 \%$ & $36.00 \%$ & 3.85 \\
\hline $\begin{array}{l}\text { Financial management } \\
\text { skills }\end{array}$ & $4.00 \%$ & $1.80 \%$ & $8.20 \%$ & $17.40 \%$ & $46.60 \%$ & $22.00 \%$ & 3.67 \\
\hline Leadership skills & $2.20 \%$ & $1.40 \%$ & $4.00 \%$ & $11.40 \%$ & $41.80 \%$ & $39.20 \%$ & 4.07 \\
\hline Legal skills & $32.40 \%$ & $5.60 \%$ & $11.80 \%$ & $22.20 \%$ & $20.60 \%$ & $7.40 \%$ & 2.15 \\
\hline Listening skills & $0.20 \%$ & $0.80 \%$ & $1.80 \%$ & $7.20 \%$ & $40.80 \%$ & $49.20 \%$ & 4.35 \\
\hline Literacy skills & $0.60 \%$ & $0.80 \%$ & $0.80 \%$ & $5.40 \%$ & $48.60 \%$ & $43.80 \%$ & 4.32 \\
\hline Management skills & $1.40 \%$ & $0.80 \%$ & $4.00 \%$ & $12.20 \%$ & $46.80 \%$ & $34.80 \%$ & 4.07 \\
\hline Marketing skills & $6.60 \%$ & $1.60 \%$ & $6.80 \%$ & $19.60 \%$ & $38.80 \%$ & $26.60 \%$ & 3.62 \\
\hline Mathematical skills & $1.60 \%$ & $0.40 \%$ & $4.60 \%$ & $12.00 \%$ & $57.20 \%$ & $24.20 \%$ & 3.95 \\
\hline Motivational skills & $5.00 \%$ & $1.00 \%$ & $4.60 \%$ & $13.80 \%$ & $42.00 \%$ & $33.60 \%$ & 3.88 \\
\hline Multitasking skills & $0.80 \%$ & $0.60 \%$ & $4.40 \%$ & $8.60 \%$ & $34.40 \%$ & $51.20 \%$ & 4.29 \\
\hline Negotiation skills & $2.00 \%$ & $1.00 \%$ & $2.60 \%$ & $10.80 \%$ & $49.20 \%$ & $34.40 \%$ & 4.07 \\
\hline
\end{tabular}

${ }^{9} \mathrm{~A}$ Cronbach Alpha of 0.905 was calculated for the variables in Table 4. 


\begin{tabular}{llllllll}
\hline Organising skills & $1.20 \%$ & $0.40 \%$ & $4.00 \%$ & $9.60 \%$ & $44.80 \%$ & $40.00 \%$ & 4.16 \\
People skills & $0.40 \%$ & $0.20 \%$ & $2.00 \%$ & $6.00 \%$ & $36.20 \%$ & $55.20 \%$ & 4.43 \\
Staff management skills & $3.00 \%$ & $0.40 \%$ & $3.60 \%$ & $10.60 \%$ & $43.40 \%$ & $39.00 \%$ & 4.08 \\
Planning skills & $0.80 \%$ & $0.60 \%$ & $4.80 \%$ & $10.00 \%$ & $50.40 \%$ & $33.40 \%$ & 4.09 \\
Presentation skills & $9.00 \%$ & $1.40 \%$ & $5.40 \%$ & $15.40 \%$ & $48.20 \%$ & $20.60 \%$ & 3.54 \\
Problem-solving skills & $1.20 \%$ & $2.00 \%$ & $1.40 \%$ & $10.60 \%$ & $46.80 \%$ & $38.00 \%$ & 4.14 \\
Research skills & $16.60 \%$ & $3.60 \%$ & $6.00 \%$ & $24.20 \%$ & $35.40 \%$ & $14.20 \%$ & 3.01 \\
Thinking skills & $0.80 \%$ & $0.20 \%$ & $0.80 \%$ & $6.80 \%$ & $44.20 \%$ & $47.20 \%$ & 4.35 \\
Time management skills & $0.60 \%$ & $1.20 \%$ & $5.40 \%$ & $7.60 \%$ & $35.00 \%$ & $50.20 \%$ & 4.26 \\
Writing skills & $0.60 \%$ & $0.60 \%$ & $1.00 \%$ & $3.20 \%$ & $40.60 \%$ & $54.00 \%$ & 4.45 \\
\hline
\end{tabular}

Source: Researchers' own construct

Stemming from the results in Table $5^{10}$, it becomes apparent that respondents did not regard it as mandatory for them to possess legal skills. Of all remaining basic business skills, the ten skills which were most appropriately developed in management, according to respondents, were as follows:

- Writing skills (94.60\% agreement).

- Literacy skills (92.40\% agreement).

- $\quad$ Thinking skills $(91.40 \%$ agreement).

- People skills (91.40\% agreement).

- Decision making skills ( $90.40 \%$ agreement).

- Listening skills (90.00\% agreement).

- Communication skills (89.80\% agreement).

- Multitasking skills (85.20\% agreement).

- Time management skills (85.20\% agreement).

- $\quad$ Problem-solving skills (84.80\% agreement).

For the sake of comparison respondents were asked to describe the overall development of basic business skills for themselves. From the results, $1.60 \%$ of respondents indicated that it was not well developed, $24.60 \%$ stated that it was developed on an average level while $75.40 \%$ mentioned that it was well developed.

Basic business skills requiring development for the achievement of key objectives and overall sustainability: Using the above as a basis, it appears that employees and management only require certain basic business skills to be developed at an appropriate level to perform their relevant tasks. Before performing any inferential statistics, respondents were asked whether the basic business skills possessed by management and employees, respectively, had any influence over the attainment of sampled SMMEs' key objectives. From the responses received, $87.40 \%$ agreed that the basic business skills possessed by employees had an influence over the attainment of key objectives of sampled SMMEs, while $93.80 \%$ agreed that the basic business skills possessed by management had an influence over the attainment of key objectives of sampled SMMEs. To determine whether the above perceptions had merit, linear regression analysis was conducted. A summary of the statistically significant results is shown in Table 6. The calculated $\mathrm{R}^{2}$ was calculated at $15.5 \%$ which indicates a weak explanation of the variances among relevant variables. Alternatively stated, there existed very few statistically significant relationships where independent variables could predict the dependent variable. This view is justified by the results - out of 56 tested relationships, only $10(17.86 \%$ of all tested relationships) were found to be statistically significant; 6 positive and 6 negative.

${ }^{10} \mathrm{~A}$ Cronbach Alpha of 0.866 was calculated for the variables in Table 5. 
Table 6: Summary of linear regression analysis results of statistically significant relationships

\begin{tabular}{|c|c|c|}
\hline & & Attainment of key objectives \\
\hline \multirow[t]{3}{*}{ Independent variables } & $\mathrm{R}^{2}$ & 0.155 \\
\hline & $\mathrm{F}$ & 1.392 \\
\hline & Sig. & 0.036 \\
\hline \multirow{2}{*}{ Employees' literacy skills } & $\operatorname{Std} \beta$ & $0.090^{*}$ \\
\hline & Sig. & 0.100 \\
\hline \multirow{2}{*}{ Employees' mathematical skills } & $\operatorname{Std} \beta$ & $-0.112 *$ \\
\hline & Sig. & 0.059 \\
\hline \multirow{2}{*}{ Employees' negotiation skills } & $\operatorname{Std} \beta$ & $-0.112 *$ \\
\hline & Sig. & 0.067 \\
\hline \multirow{2}{*}{ Employees' time-management skills } & $\operatorname{Std} \beta$ & $0.125^{* *}$ \\
\hline & Sig. & 0.039 \\
\hline \multirow{2}{*}{ Employees' writing skills } & $\operatorname{Std} \beta$ & $-0.145^{* *}$ \\
\hline & Sig. & 0.019 \\
\hline \multirow{2}{*}{ Management's administration skills } & $\operatorname{Std} \beta$ & $-0.149 *$ \\
\hline & Sig. & 0.079 \\
\hline \multirow{2}{*}{ Management's mathematical skills } & $\operatorname{Std} \beta$ & $0.109^{*}$ \\
\hline & Sig. & 0.055 \\
\hline \multirow{2}{*}{ Management's research skills } & $\operatorname{Std} \beta$ & $0.118 * *$ \\
\hline & Sig. & 0.042 \\
\hline \multirow{2}{*}{ Management's time management skills } & $\operatorname{Std} \beta$ & $-0.162 * * *$ \\
\hline & Sig. & 0.004 \\
\hline \multirow{2}{*}{ Management's writing skills } & $\operatorname{Std} \beta$ & $0.127^{* *}$ \\
\hline & Sig. & 0.027 \\
\hline $\begin{array}{l}\text { *Statistically significant at the } 10 \% \text { level } \\
* * \text { Statistically significant at the } 5 \% \text { level } \\
* * * \text { Statistically significant at the } 1 \% \text { level }\end{array}$ & & \\
\hline
\end{tabular}

Source: Researchers' own construct

When placing emphasis on the results in Table 6, it becomes apparent that the attainment of sampled SMMEs' key objectives was statistically significantly positively influenced by management's mathematical skills $(\beta=$ $0.109)$, research skills $(\beta=0118)$, and writing skills $(\beta=0.127)$.In addition, the attainment of key objectives in sampled SMMEs was statistically significantly negatively influenced by management's administration skills $(\beta=-0.149)$ and time management skills $(\beta=-0.162)$.Thus the following statistically significant predictions can be made with at least $90 \%$ confidence:

- When sampled SMMEs' management improves their mathematical skills, research skills and writing skills, it will have a statistically significant positive influence on the attainment of key business objectives.

- When sampled SMMEs' management improves their administration skills and time management skills, it will have a statistically significant negative influence on the attainment of key business objectives.

Reverting to Table 6, it also appears that the attainment of sampled SMMEs' key objectives was statistically significantly positively influenced by employees 'literacy skills $(\beta=0.090)$ and time management skills $(\beta=$ 0.125). Furthermore, the attainment of key objectives in sampled SMMEs was statistically significantly negatively influenced by employees' mathematical skills $(\beta=-0.112)$, negotiation skills $(\beta=-0.112)$, and writing skills $(\beta=-0.145)$.

Thus the following statistically significant predictions can be made with at least $90 \%$ confidence:

- When sampled SMMEs' employees improve their literacy skills and time management skills, it will have a statistically significant positive influence on the attainment of key business objectives. 
- When sampled SMMEs' employees improve their mathematical skills, negotiation skills and writing skills, it will have a statistically significant negative influence on the attainment of key business objectives.

Although the statistically significant predictions above are straight-forward, the reasons for these predictions are not clear. It may be probable that if management spends too much time on mundane tasks (which can be outsourced), that they do not add optimal value to sampled SMMEs which may adversely influence the attainment of key objectives. In addition, it may also be probable that if employees became too skilled with managerial-related tasks, that they may abuse their positions ("freedom" to act on management's behalf) in sampled SMMEs. Regardless of the possible reasons, this is an avenue for further research. Notwithstanding the above, no concrete evidence is provided to accept $\mathrm{H}_{1}$ and $\mathrm{H}_{2}$ as majority of tested relationships were statistically insignificant (82.14\% of all tested relationships) resulting in the rejection of both hypotheses.

\section{Conclusion}

According to popular literature there is a need for the development of basic business skills in South Africa, particularly in SMMEs. Although no previous study has been conducted on the individual basic business skills which need development in South African SMMEs, this study was conducted with the main intent to explore the latter phenomena. From the research conducted it was found that certain basic business skills are more important to possess than others in sampled South African SMMEs, in order to perform relevant tasks. For example, legal skills and research skills were regarded as unnecessary for employees to have while only legal skills (to some extent) were regarded as unnecessary for management to possess. Notwithstanding the aforementioned, both management and employees were perceived, by respondents, to have properly developed basic business skills. When focus was shifted to the basic business skills which should be developed in sampled South African SMMEs, to assist in the attainment of key objectives, the results showed that an improvement in management's mathematical skills, and research skills and writing skills, and employees' literacy skills and time management skills had a statistically significant positive influence thereon. Regardless of the fact that the results of the study rejected both developed hypotheses, conducting the same research study in a different geographical region and/or industry may yield different results. Hence, it may still be probable that the development of basic business skills in South African SMMEs may actually have a positive influence on the attainment of key business objectives.

\section{References}

Anderson, L. \& Krathwohl, D. (2001). A taxonomy for learning, teaching, and assessing: A revision of Bloom's taxonomy of educational objectives. New York: Longman.

Ashipala, J. (2010). Determinants of Unemployment in Namibia. International Journal of Business and Management, 5(10), 92-104.

Biyase, L. (2009). DTI to look at how crisis hurts small enterprises. The Star.

Bose, S.\& Pekny, J. (2000). A model predictive framework for planning and scheduling problems: A case study of consumer goods supply chain. Computers and Chemical Engineering, 24(2-7), 329-335.

Brand, R., Du Preez, N. \& Schutte, C. (2007). A business framework to network small South African enterprises for sustainability. South African Journal of Industrial Engineering, 18(2), 187-201.

Bruwer, J. P. (2016). The relationship(s) between the managerial conduct and the internal control activities of South African fast moving consumer goods Small, Medium and Micro Enterprises. Cape Peninsula University of Technology. Cape Town: Unpublished Manusript (thesis).

Bruwer, J. P. \& Van Den Berg, A. (2017). The Conduciveness of the South African Economic Environment and Small, Medium and Micro Enterprise Sustainability: A Literature Review. Expert Journal of Business and Management, 5(1), 1-12.

Cameron, J. (2014). Critical skills list: Foreigners wanted for jobs we can't do - full details. Retrieved from http://www.fin24.com/BizNews/Critical-skills-list-Foreigners-wanted-for-jobs-we-cant-do-fulldetails-20141113

Cant, M. \& Wiid, J. (2013). Establishing the challenges affecting South African SMEs. International Business \& Economics Research Journal, 12(6), 707-716. 
Cant, M., Erdis, C. \& Sephapo, C. (2014). Business Survival: The Constraints Experienced by South African SMEs in the Financial Sector. International Journal of Academic Research in Business and Social Sciences, 4(10), 565-579.

Clover, T. \& Darroch, M. (2005). Owners' perceptions of factors that constrain the survival and growth of small, medium and micro agribusinesses in KwaZulu-Natal, South Africa. Agrekon, 44(2), 238-263.

Cole, M. (2015). Is South Africa Operating in a Safe and Just Space? Using the doughnut model to explore environmental sustainability and social justice. London: Oxfam.

Dahlqvist, J., Davidsson, P. \& Wiklund, J. (2000). Initial Conditions as Predictors of New Venture Performance: A Replication and Extension of the Cooper et al study. Enterprise and Innovation Management Studies, 1(1), 1-17.

Daniels, R. (2007). Skills Shortages in South Africa: A Literature Review. Development Policy Research Unit, DPRU Working Paper 07/121.

Demetriou, A., Shayer, M. \& Efklides, A. (2016). Neo-Piagetian Theories of Cognitive Development: Implications and Applications for Education. Routledge.

DHET. (2015). List of occupations in high demand: 2015. Retrieved from http://www.dhet.gov.za/Gazette/Government\%20Gazette\%20No\%2039604,\%2019\%20January\%2 02016.\%20List\%20of\%200ccupations\%20in\%20High\%20Demand\%202015.pdf

Dictionary, B. (2017). Skill. Retrieved from http://www.businessdictionary.com/definition/skill.html

Duncan, F. (2014). SA has a serious talent problem - education, brain drain and quality of life. Retrieved from http://www.biznews.com/thought-leaders/2014/12/03/sa-serious-talent-problem-educationbrain-drain-quality-life/

FASSET. (2015). Scarce Skills Guideline. Retrieved from http://www.fasset.org.za/downloads/Scarce_Skills_Guide_2015_V7.pdf

Fatoki, O. (2014). Enhancing access of external finance for new micro enterprises in South Africa. Journal of Economics, 5(1), 1-6.

Fischer, K. (1980). A Theory of Cognitive Development: The Control and Construction of Hierarchies of Skills. Psychological Review, 47(6), 477-531.

Fransman, T. (2014). English proficiency as a labour market determinant: South African Black males. University of the Western Cape. Cape Town: Unpublished Manuscript (thesis).

García-Magariño, I., Gómez-Sanz, J. \& Fuentes-Fernández, R. (2009). Model transformations for improving multi-agent system development in INGENIAS. International Workshop on Agent-Oriented Software Engineering.

Grant, L. (2015). Retrieved from Infographic: Poverty in South Africa: https://mg.co.za/data/2015-02-05infographic-poverty-in-south-africa

Herrington, M., Kew, J. \& Kew, P. (2010). Global Entrepreneurship Monitor 2010 Report. Retrieved from http://www.gsb.uct.ac.za/files/gem2010report.pdf

Höppli, T. (2014). New evidence on the Brain Drain from South Africa. Policy Research on International Services and Manufacturing, Working Paper 1/2014.

IOL. (2008). Reasons behind South Africa's Skills Shortage. Retrieved from http://www.iol.co.za/news/southafrica/reasons-behind-sas-skills-shortage-388859

Jeon, C., Amekudzi, A. \& Guensler, R. (2010). Evaluating plan alternatives for transportation system sustainability: Atlanta metropolitan region. International Journal of Sustainable Transportation, 4(4), 227-247.

Kirschner, P., Van Vilsteren, P., Hummel, H. \& Wigman, M. (1997). The design of a study environment for acquiring academic and professional competence. Studies in Higher education, 22(2), 151-171.

Kunene, T. (2008). A critical analysis of entrepreneurial and business skills in SMEs in the textile and clothing industry in Johannesburg, South Africa. University of Pretoria. Pretoria: Unpublished Manuscript (thesis).

Lebacq, T., Baret, P. \& Stilmant, D. (2013). Sustainability indicators for livestock farming: a review. Agronomy for Sustainable Development, 33(2), 311-327.

Mamabolo, M., Kerrin, M. \& Kele, T. (2017). Entrepreneurship management skills requirements in an emerging economy: A South African outlook. The Southern African Journal of Entrepreneurship and Small Business Management, 9(1), 1-10.

Masson, M. (1990). Cognitive theories of skill acquisition. Human Management Science, 9(1), 221-239. 
Mateus, A., Allen-Ile, C. \& Iwu, C. (2014). Skills Shortage in South Africa: Interrogating the Repertoire of Discussions. Mediterranean Journal of Social Sciences, 5(6), 36-73.

Meyer, D. (2016). Predictors of poverty: A comparative analysis of low income communities in the Northern Free State region, South Africa. International Journal of Social Sciences and Humanity Studies, 8(2), 132-149.

Mittelstaedt, E. \& Wiepcke, C. (2007). Ökonomische Bildung zur nachhaltigen Entwicklung von Business Skills.

Moloi, N. (2013). The sustainability of construction small-medium enterprises (SMEs) in South Africa. University of Witwatersrand. Johannesburg: Unpublished Manuscript (dissertation).

Mouloungui, S. (2012). Assessing the impact of finance on small business development in Africa: the cases of South Africa and Gabon. Tswane University of Technology. Twsane: Unpublished Manuscript (dissertation).

Mughan, T., Lloyd-Reason, L. \& Zimmerman, C. (2004). Management Consulting and International Business Support for SMEs: Need and Obstacles. Education and Training, 46(8/9), 424-432.

Nagarajan, G. \& Sheriff, J. (2013). Emerging challenges and prospects of FMCG product development in India. International Journal of Marketing, Financial Services \& Management Research, 2(1), 41-52.

Naidoo, R. \& Urban, B. (2010). The relevance of operational skills towards business sustainability: a focus on SMME manufacturers in the Vaal Triangle region. Acta Commercii, 10(1), 234-248.

OECD. (2015). OECD Economic Surveys: South Africa 2015. Retrieved from http://www.treasury.gov.za/publications/other/OECD\%20Economic\%20Surveys\%20South\%20Afr ica\%202015.pdf

Olawale, F. \& Garwe, D. (2010). Obstables to the growth of new SMEs in South Africa: A principal component analysis approach. African Journal of Business Management, 4(5), 729-738.

Onoh, B. (2011). Basic Accounting Skills Needed by self-Employed Building craftsmen Through Entrepreneurship Education. International Technology Research Journal, 2(1).

Panco, R. \& Korn, H. (1999). Understanding factors of organizational mortality: considering alternatives to firm failure. Retrieved from http://www.eaom.org/AnnualMeetings/Philadelphia1999/Papers/PancoRobert.html

Polity. (2013). Statement by the National Treasury, on the Youth Employment Tax Incentive. Retrieved from http://www.polity.org.za/print-version/sa-statement-by-the-national-treasury-on-the-youthemployment-tax-incentive-20092013-2013-09-20

Radas, S. \& Božić, L. (2009). The antecedents of SME innovativeness in an emerging transition economy. Technovation, 29(6-7), 438-450.

Ramukumba, T. (2014). Overcoming SMEs challenges through critical success factors: A case of SMEs in the Western Cape Province. South Africa. Economic and Business Review, 16(1), 19-38.

SAICA. (2015). SAICA history. https://www.saica.co.za/About/SAICAHistory/tabid/70/language/en-ZA/Default.aspx

Siwangaza, L., Smit, Y., Bruwer, J. P. \& Ukpere, W. (2014). The status of internal controls in fast moving small medium and micro consumer goods enterprises within the Cape Peninsula. Mediterranean Journal of Social Sciences, 5(10), 163-175.

South Africa. (1996). National Small Business Act No. 102 of 1996. Pretoria: Government Printer.

South Africa. (2016). National Assessment Curricula No. 3 of 2016. Pretoria: National Government.

Strydom, J. W.\& Tustin, D. (2003). Small business skills audit in PERI-URBAN areas of Northern Tshwane. Bureau of Market Research.

Thabethe, E. (2013). Speaker at the SMME Breakfast Seminar. Bulawayo, Zimbabwe.

Thórisson, K., Nivel, N., Steunebrink, B., Helgason, H., Pezzulo, G., Sanz Bravo, R.\& Jonsson, G. (2014). Autonomous Acquisition of Natural Situated Communication. IADIS International Journal on Computer Science And Information Systems, 9(2), 115-131.

Thornhill, S.\& Amit, R. (2003). Learning about failure: bankruptcy, firm age and the resource based view. Organisation Science, 14(5), 497-509.

Trading Economics. (2017). South Africa Unemployment Rate. Retrieved from http://www.tradingeconomics.com/south-africa/unemployment-rate

Tregenna, F.\& Tsela, M. (2012). Inequality in South Africa: The distribution of income, expenditure and earnings. Development Southern Africa, 29(1), 35-61. 
Van Calker, K., Berentsen, P., Giesen, G.\& Huirne, R. (2005). Identifying and ranking attributes that determine sustainability in Dutch dairy farming. Agriculture and Human Values, 22(1), 53-63.

Wiese, J. (2014). Factors determining the sustainability of selected small and medium-sized enterprises. North-West University. Potchefstroom: Unpublished Manuscript (thesis).

Woolard, I., Kneebone, P.\& Lee, D. (2003). Human resources development review 2003: Education, employment and skills in South Africa. Cape Town: HSR.

World Bank. (2017).Country Dashboard: South Africa. Retrieved from http://povertydata.worldbank.org/poverty/country/ZAF

World Economic Forum. (2014). Matching Skills and Labour Market Needs - Building Social Partnerships for Better Skills and Better Jobs.Global Agenda Council on Employment.

Worldometers. (2017). South Africa Population. Retrieved from http://www.worldometers.info/worldpopulation/south-africa-population/. 